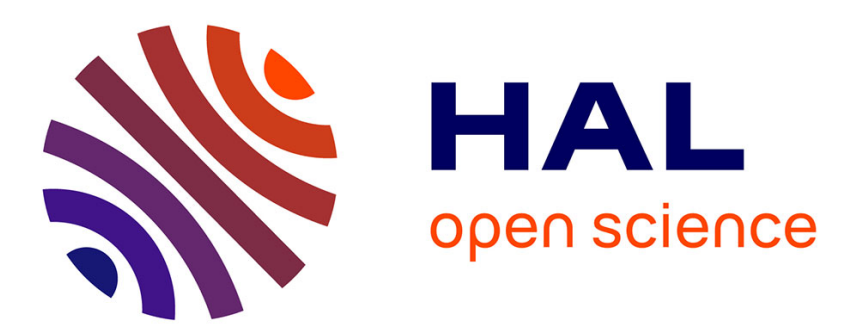

\title{
Base and Extended One-Dimensional Warranties Analyses for Remanufactured Products
}

\author{
Ammar Y. Alqahtani, Surendra M. Gupta
}

\section{To cite this version:}

Ammar Y. Alqahtani, Surendra M. Gupta. Base and Extended One-Dimensional Warranties Analyses for Remanufactured Products. IFIP International Conference on Advances in Production Management Systems (APMS), Sep 2016, Iguassu Falls, Brazil. pp.389-397, 10.1007/978-3-319-51133-7_46 . hal01615724

\author{
HAL Id: hal-01615724 \\ https://hal.inria.fr/hal-01615724
}

Submitted on 12 Oct 2017

HAL is a multi-disciplinary open access archive for the deposit and dissemination of scientific research documents, whether they are published or not. The documents may come from teaching and research institutions in France or abroad, or from public or private research centers.
L'archive ouverte pluridisciplinaire HAL, est destinée au dépôt et à la diffusion de documents scientifiques de niveau recherche, publiés ou non, émanant des établissements d'enseignement et de recherche français ou étrangers, des laboratoires publics ou privés. 


\title{
Base and Extended One-Dimensional Warranties Analyses for Remanufactured Products
}

\author{
Ammar Y. Alqahtani ${ }^{1}$ and Surendra M. Gupta ${ }^{2}$ \\ ${ }^{1}$ King Abdulaziz University, Jeddah, Saudi Arabia \\ aaylqahtani@kau.edu.sa \\ ${ }^{2}$ Northeastern University, Boston, Massachusetts, U.S.A. \\ gupta@neu.edu
}

\begin{abstract}
Uncertainties in the quality and reliability of remanufactured products from the buyer's perspective might lead to a decision of not buying it. Remanufacturers must search for market mechanisms that provide assurance about the durability of remanufactured products. This paper considers a Remanufacturing-To-Order (RTO) system for sensor embedded products (SEPs). It presents an approach to determine how to predict base warranty (BW) and extended warranty $(\mathrm{EW})$ periods for the remanufactured products using the sensor information about the age of each of the end-of-life (EOL) components on hand to meet the demand while minimizing the cost associated with warranty, maximizing manufacturer's profit and finding an attractive price for the extended warranty. An example is considered to illustrate the implementation of the model.
\end{abstract}

Keywords: Reverse Supply Chain, Simulation, Non-Renewable Warranty Policies, Closed Loop Supply Chain.

\section{Introduction}

Management at the end-of-life (EOL) stage of products has been a topic of interest of many researchers. This is because of environmental factors, government regulations, public demands, and in recent years potential economic benefits that could be realized by implementing reverse logistics and product recycling policies. For this, companies need to remanufacture or come up with schemes to minimize the amount of waste sent to landfills by recovering materials and components from end-of-life products (EOLPs).

The quality of a remanufactured product is often a suspect for consumers. That is, the consumers are unsure if the remanufactured products will render the expected performance. This ambiguity about a remanufactured product could lead the consumer to decide against buying it. With such apprehension held by consumers, remanufacturers must seek market mechanisms that provide assurance about the durability of the products. One strategy that the remanufacturers could use is to offer warranties on their products [1]. 


\section{$2 \quad$ Literature Review}

\subsection{Environmentally Conscious Manufacturing and Product Recovery}

Reviews of wide-ranging issues in environmentally conscious manufacturing and product recovery are offered by Gungor and Gupta [2] and Ilgin and Gupta [3]. Disassembly is the most common feature in remanufacturing research area. For different aspects of disassembly, see the book by Lambert and Gupta [4].

In recent years, many scholars have studied remanufacturing processes because traditional production planning methods fall short in product recovery settings. A review of 76 journal articles on remanufacturing was reported by Lage and Godinho Filho [5]. For additional aspects of remanufacturing, see the book by Ilgin and Gupta [6].

\subsection{Warranty Analysis}

Product warranties have three key roles. The first role is insurance and protection, allowing consumers to transfer the risk of product failure to sellers [7]. Next, product warranties can also signal product reliability to customers $[8,9,10,11]$. Lastly, the sellers use warranties to extract additional profitability [12]. There are several references that consider basic and extended warranty policies analysis for new products' supply chain management $[13,14,15]$. However, there are a few that consider the warranty for remanufactured products' reverse and closed-loop supply chain management $[16,17,18,19]$. Modeling and analyzing the warranty cost for used product is a new research field with a limited number of publications.

\section{Remanufacturing-To-Order System Description}

The Remanufacturing-To-Order (RTO) system considered in this study is a product recovery system. A sensor embedded air conditioner (AC) is considered here as an example product. Based on the condition of EOL AC, it will go through a series of recovery operations as shown in Figure 1.

EOL ACs arrive at the RTO system for information retrieval using sensor reader. The information retrieved is stored in the facility's database. Then the ACs go through a six-station disassembly line. Complete disassembly is performed to extract every single component. There are nine components in an AC consisting of, evaporator, control box, blower, air guide, motor, condenser, fan, protector, and compressor as shown in Figure 2. Exponential distributions are used to generate the disassembly times at each station, interracial times of each component's demand, and interarrival times of EOL AC. Two different types of disassembly operations, viz., destructive or nondestructive, are used depending on the component's condition. If the disassembled component is nonfunctional (broken, zero remaining life), then destructive disassembly is used such that the other components' functionalities are not damaged. Unit disassembly cost for a functional component is higher than nonfunctional component.

Recovery operations differ for each SEP based on its condition and estimated remaining life. Recovered products and components are characterized based on their 
remaining life times and are placed in different life-bins (e.g. 1 year, 2 years, etc.) where they wait to be retrieved via a customer demand.

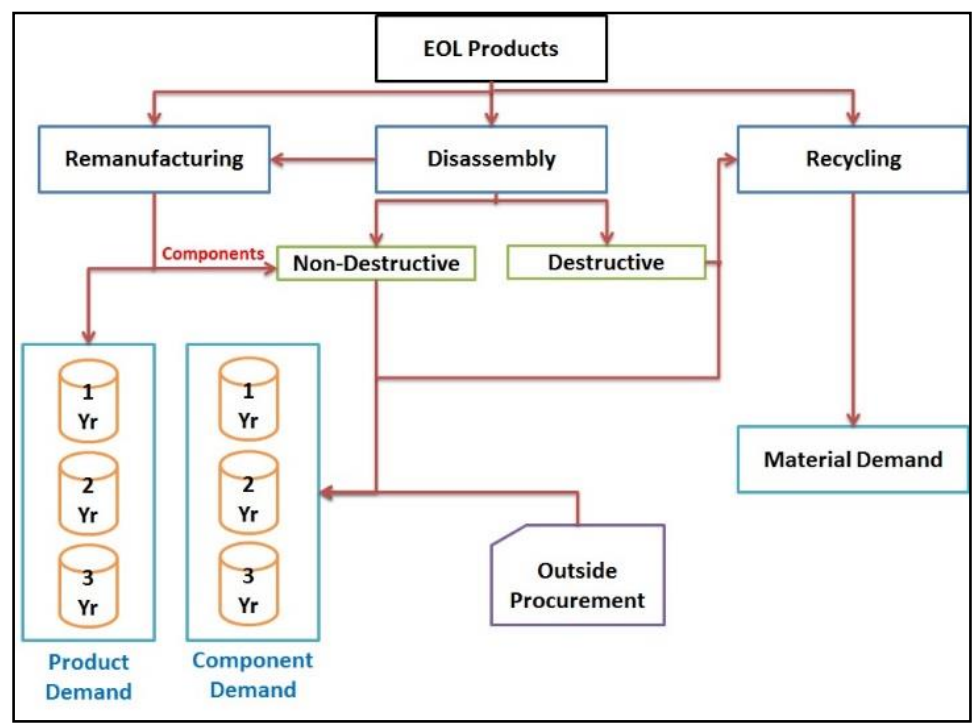

Fig. 1. RTO System's recovery processes

\section{$4 \quad$ Warranty Cost Analysis}

In the process of deciding to purchase a product, the buyers usually compare features of the product with other competing brands that are selling the same product. In some cases, the competing brands make similar products with similar features such as cost, special characteristics, quality and credibility of the product and even insurance from the provider. In such cases, the sale is influenced by such factors as discount, availability of parts, repairs and additional services. These factors may be very significant to the buyer and can be further enhanced by offering warranty to the buyer as it further assures the buyer of the reliability of the product.

A warranty is an agreement that requires the manufacturer to correct any product failures or compensates the buyer for any problems that occur with the product during the warranty period in relevance to its sale. A base warranty (BW) is typically associated with products. It is a predetermined agreement between a remanufacturer and a buyer at the time the product is bought. On the other hand, the extended warranty (EW) is purchased separately and the buyer may even have a choice of terms.

Nowadays, EWs are offered on a wide range of products, including automobiles, electronics and appliances. Usually, the buyer has to buy an EW at the same time as the product is purchased with extra amount separated from the product's price depending on the duration and the terms of the EW. In contrast, a BW is integral to the sale of a product and the customer does not pay anything extra for it.

There are different base and extended warranty types that most manufacturers offer to their buyers. The most popular policies are the Free Replacement Warranty (FRW) 
and Pro-Rata Warranty (PRW). The main expense of the extended warranty is the cost of the product plus the cost of servicing an item that fails during the extended warranty period. The warranty cost is the expense of servicing all warranty claims for a product during the overall period of the warranty (base and extended).

\section{$5 \quad$ Notation and Formulation for Warranty Cost}

The nomenclature used in this paper is given in Table 1 .

Table 1. Parameters used in BW and EW

\begin{tabular}{|c|l|}
\hline Parameters: & Definition: \\
\hline$L$ & Life cycle (remaining life) \\
\hline$X$ & Time to failure of an item \\
\hline$W_{B}$ & Length of base warranty period \\
\hline $\mathrm{W}_{\mathrm{E}}$ & Length of extended warranty period \\
\hline$C s$ & Cost to the remanufacturer of supplying a remanufactured item \\
\hline$C p$ & Sales price per unit \\
\hline$C r$ & Average cost of each repair \\
\hline$M T T F$ & Mean time to failure \\
\hline$\alpha$ & $\begin{array}{l}\text { Weibull distribution shape parameter, } 0 \leq \alpha \leq 1 \\
\text { MTTF }=20 \text { Days, } \alpha=2, \text { MTTF }=40 \text { Days and } \alpha=3, \text { MTTF }=60\end{array}$ \\
\hline$M\left(W_{B}\right)$ & Days $)$ \\
\hline$M\left(W_{E}\right)$ & Average number of replacement during the base warranty period \\
\hline$M\left(W_{B}+W_{E}\right)$ & Average number of replacement during the extended warranty \\
\hline$\mu_{W}$ & Period \\
\hline$f(x)$ & Expertial expectation of X \\
\hline$K_{W}$ & Long-run average proportion of rebate \\
\hline$C\left(W_{B}\right)$ & Expected based warranty servicing cost \\
\hline$C\left(W_{B} ; W_{E}\right)$ & Expected extended warranty servicing cost \\
\hline$C_{E}\left(W_{B} ; W_{E}\right)$ & Expected extended warranty servicing cost per unit sale \\
\hline$C\left(W_{B}+W_{E}\right)$ & Expected total (based + extended) warranty period servicing cost \\
\hline & \\
\hline
\end{tabular}

\subsection{Base Free Replacement Warrantee (FRW) Formulation:}

The expected warranty cost could be calculated using Blischke and Murthy [1] formula as follows:

$$
\text { Expected warranty cost }=C s .[1+M(W)]
$$




\subsection{Base Pro-Rata Warranty (PRW) Formulation:}

The PRW expected cost to remanufacturer is given by Blischke and Murthy [1] as follows:

$$
\begin{gathered}
\text { Average cost per unit }=C_{s}+C_{p} \cdot\left[F(W)-\mu_{W} / W\right] \\
\mu_{W}=\int_{0}^{W} x f(x) d x \\
\text { Expected cost to the remanufacturer of a warranty }=C_{s}+K_{w} . C_{p} \\
\text { Rebate }=\left[\left(1-\frac{X}{W}\right) / C_{p}\right]
\end{gathered}
$$

\subsection{Extended Free Replacement Warrantee (FRW) Formulation:}

The expected EW servicing cost per unit sale is given by Blischke and Murthy [20] as follows:

$$
\begin{aligned}
& E\left[C_{E}\left(W_{B} ; W_{E}\right)\right]=E\left[C\left(W_{B}+W_{E}\right)\right]-E\left[C\left(W_{B}\right)\right] \\
& E\left[C\left(W_{B}\right)\right]=C s .\left[1+M\left(W_{B}\right)\right] \\
& \left.E\left[C\left(W_{B}+W_{E}\right)\right]=C s .\left[M\left(W_{B}+W_{E}\right)\right]-M\left(W_{B}\right)\right]
\end{aligned}
$$

\section{Numerical Example}

An AC with three different remaining lives (1 year, 2 years and 3 years) is sold with a base FRW or PRW policy. The relevant cost elements are the cost of providing the $\mathrm{AC}$ and the expected cost of servicing all warranty claims in case of FRW or the expected amount of the rebate in case of PRW. To examine the effect of fluctuating the warranty period, warranty lengths of $\mathrm{W}=30,60$, and 90 days are considered.

Moreover, the example considers extended FRW policy for the remanufactured AC's components and products with three different remaining lives (1 year, 2 years and 3 years), 90 days base warranty period and three different extended warranty periods (1 year, 2 years and 3 years). The AC failure follows a Weibull distribution with a mean time to failure MTTF of the $\mathrm{AC}=0.5$ years. The other data used for the implementation of the model is shown in Table 2.

\section{$7 \quad$ Results}

All results in this section were obtained using ARENA 14.0 program to compute the expected number of failures and expected cost to remanufacturer.

\subsection{Case I: Base Free Replacement Warrantee (FRW):}

In Table 3, expected number of failures represent the expected number of failed items per unit sale. In other words, it is the average number of free replacements that the remanufacturer would have to provide per unit sold during the warranty period. Expected cost to remanufacturer includes the cost of supplying the original item, Cs. Thus, the expected cost of warranty is calculated by subtracting $C s$ from the expected cost to remanufacturer. 
Although not showing in the table, the expected cost of warranty to the remanufacturer can easily be calculated for $\mathrm{W}=30,60$, and 90 days. For example, for $W=30$ and $\alpha=1$, the warranty cost for $\mathrm{AC}$ is $\$ 57.50-C s=\$ 57.50-\$ 55.50=\$ 2.50$ which is $([\$ 2.50 / \$ 55.00] \times 100)=4.5 \%$ of the cost of supplying the item, $C s$, which is significantly less than that $\$ 55.00, C s$. This may be acceptable, but the corresponding values for longer warranties become excessive. For example, for 90 days and $\alpha=1$, corresponding percentage is $([\$ 70.50-\$ 55.00 / \$ 55.00] \times 100)=28.18 \%$.

Table 2. Operation costs, sale price and repair cost for AC components

\begin{tabular}{|c|c|c|c|c|c|}
\hline \multirow[b]{2}{*}{ Product } & \multirow[b]{2}{*}{$\begin{array}{c}C_{s}=\text { Operation } \\
\text { costs (\$/unit) }\end{array}$} & \multicolumn{3}{|c|}{$C_{p}=$ Sale Price (\$/unit) } & \multirow[b]{2}{*}{$\begin{array}{c}C_{r}=\text { Repair } \\
\text { costs (\$/unit) }\end{array}$} \\
\hline & & $\begin{array}{l}L=1 \\
\text { Year }\end{array}$ & $\begin{array}{l}L=2 \\
\text { Years }\end{array}$ & $\begin{array}{l}L=3 \\
\text { Years }\end{array}$ & \\
\hline $\mathrm{AC}$ & $\$ 55.00$ & $\$ 180$ & $\$ 240$ & $\$ 310$ & $\$ 85.00$ \\
\hline
\end{tabular}

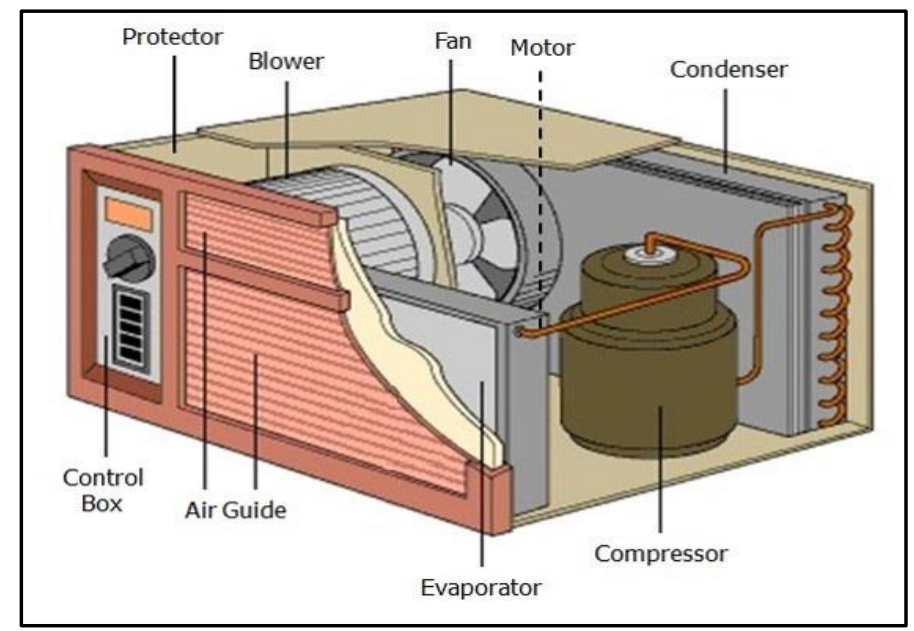

Fig. 2. Air Conditioner (AC) components

Table 3. Expected number of failures and cost for remanufactured AC during BW

\begin{tabular}{|c|c|c|c|c|c|c|c|}
\hline \multirow{3}{*}{ Product } & \multirow{2}{*}{$\begin{array}{c}\boldsymbol{W} \\
\text { (days) }\end{array}$} & \multicolumn{3}{|c|}{$\begin{array}{c}\text { Expected number of } \\
\text { failures }\end{array}$} & \multicolumn{3}{c|}{$\begin{array}{c}\text { Expected cost to } \\
\text { remanufacturer }\end{array}$} \\
\cline { 3 - 8 } & & $\boldsymbol{\alpha}=\mathbf{1}$ & $\boldsymbol{\alpha}=\mathbf{2}$ & $\boldsymbol{\alpha}=\mathbf{3}$ & $\boldsymbol{\alpha}=\mathbf{1}$ & $\boldsymbol{\alpha}=\mathbf{2}$ & $\boldsymbol{\alpha}=\mathbf{3}$ \\
\hline \multirow{3}{*}{ AC } & $\mathbf{3 0}$ & 0.0120 & 0.0054 & 0.00046 & $\$ 57.50$ & $\$ 55.16$ & $\$ 54.64$ \\
\cline { 2 - 8 } & $\mathbf{6 0}$ & 0.1900 & 0.0218 & 0.00339 & $\$ 60.00$ & $\$ 60.65$ & $\$ 57.20$ \\
\cline { 2 - 8 } & $\mathbf{9 0}$ & 0.2490 & 0.0485 & 0.01102 & $\$ 70.50$ & $\$ 69.45$ & $\$ 59.33$ \\
\hline
\end{tabular}

\subsection{Case II: Base Pro-Rata Warranty (PRW):}

The result of all ACs ( 1 year, 2 years and 3 years remaining life) $K_{W}$ values for different mean times to failure represented by $\alpha$ and warranty periods are calculated in Table 4. For instance, from Table 4 a 1 year remaining life AC with a median time to 
failure of 20 days and a 30 days warranty has $K_{W}=0.1346$, i.e., the cost of the warranty is $0.1346 \times C p$. Therefore, if the total cost of the 1 year AC to the remanufacturer is $\$ 55$ and it sells for $\$ 180$, the cost to the remanufacturer, including warranty, is $\$ 55+(0.1346) \times 180=\$ 79.23$.

\subsection{Case III: Extended Free Replacement Warrantee (FRW):}

Table 5 shows the expected EW cost of all AC's components and products for $\mathrm{W}_{\mathrm{E}}=$ 1, 2, 3 years. Also, it shows the expected number of failures as the expected number of failed items per unit sale. In other words, it is the average number of free replacements that the remanufacturer would have to provide per unit sold during the warranty period. Note that, the expected cost to remanufacturer includes the cost of supplying the original item, Cs. Thus the expected cost of warranty alone is calculated by subtracting $C_{s}$ from the expected cost to remanufacturer.

The results given in Table 5 are useful in order to choose the length of an extended FRW warranty. The cost of the warranty is dependent on the value of Weibull shape parameters $\alpha$. For example, the EW for 3 years remaining life AC with $\alpha=1$ will cost $\$ 104.44-\$ 55.00=\$ 49.44$ which is $81 \%$ of $C s$.

Table 4. Factor $K_{W}$ for calculating remanufacturer's cost of base PRW policy

\begin{tabular}{|c|c|c|c|c|}
\hline $\begin{array}{c}\text { AC Remaining } \\
\text { Life }\end{array}$ & \multirow{2}{*}{$\begin{array}{c}|c| \\
\text { MTTF }\end{array}$} & $\boldsymbol{W}=\mathbf{3 0}$ & $\boldsymbol{W}=\mathbf{6 0}$ & $\boldsymbol{W}=\mathbf{9 0}$ \\
\cline { 2 - 5 } 1 Year AC & $\boldsymbol{\alpha}=\mathbf{1}$ & 0.1346 & 0.1883 & 0.2335 \\
\cline { 2 - 5 } & $\boldsymbol{\alpha}=\mathbf{2}$ & 0.1183 & 0.1437 & 0.1793 \\
\cline { 2 - 5 } & $\boldsymbol{\alpha}=\mathbf{3}$ & 0.0851 & 0.1199 & 0.1457 \\
\hline \multirow{3}{*}{ 2 Years AC } & $\boldsymbol{\alpha}=\mathbf{1}$ & 0.2667 & 0.3390 & 0.4011 \\
\cline { 2 - 5 } & $\boldsymbol{\alpha}=\mathbf{2}$ & 0.2110 & 0.2620 & 0.3232 \\
\cline { 2 - 5 } & $\boldsymbol{\alpha}=\mathbf{3}$ & 0.1727 & 0.2245 & 0.2665 \\
\hline \multirow{3}{*}{ 3 Years AC } & $\boldsymbol{\alpha}=\mathbf{1}$ & 0.2878 & 0.3349 & 0.3870 \\
\cline { 2 - 5 } & $\boldsymbol{\alpha}=\mathbf{2}$ & 0.2101 & 0.2622 & 0.3244 \\
\cline { 2 - 5 } & $\boldsymbol{\alpha}=\mathbf{3}$ & 0.1740 & 0.2273 & 0.2628 \\
\hline
\end{tabular}

Table 5. Expected number of failures and cost for remanufactured AC during EW

\begin{tabular}{|c|c|c|c|c|c|c|c|}
\hline \multirow{3}{*}{ Product } & \multirow{2}{*}{$\begin{array}{c}\boldsymbol{W} \\
\text { (years) }\end{array}$} & \multicolumn{3}{|c|}{$\begin{array}{c}\text { Expected number of fail- } \\
\text { ures }\end{array}$} & \multicolumn{3}{|c|}{$\begin{array}{c}\text { Expected cost to } \\
\text { remanufacturer }\end{array}$} \\
\cline { 3 - 8 } & & $\boldsymbol{\alpha}=\mathbf{1}$ & $\boldsymbol{\alpha}=\mathbf{2}$ & $\boldsymbol{\alpha}=\mathbf{3}$ & $\boldsymbol{\alpha}=\mathbf{1}$ & $\boldsymbol{\alpha}=\mathbf{2}$ & $\boldsymbol{\alpha}=\mathbf{3}$ \\
\hline \multirow{3}{*}{$\mathrm{AC}$} & $\mathbf{1}$ & 0.0837 & 0.0517 & 0.0447 & $\$ 62.11$ & $\$ 59.39$ & $\$ 58.80$ \\
\cline { 2 - 8 } & $\mathbf{2}$ & 0.4608 & 0.2288 & 0.1135 & $\$ 94.17$ & $\$ 74.45$ & $\$ 64.65$ \\
\cline { 2 - 8 } & $\mathbf{3}$ & 0.5817 & 0.3497 & 0.1436 & $\$ 104.44$ & $\$ 84.72$ & $\$ 67.21$ \\
\hline
\end{tabular}

\section{Conclusion}

The Base Warranty (BW) and Extended Warranty (EW) costs for remanufactured products and components were evaluated in this paper using the one-dimensional Free Replacement Warranty (FRW) policy and Pro-Rata Warranty (PRW) for different 
periods. The main objective was to introduce the idea of providing a base and an extended warranty for a remanufactured product and how to predict a warranty period for using the sensor information about the age of each and every EOL product on hand to meet product demand while minimizing the cost associated with warranty and maximizing manufacturer's profit.

\section{References}

1. Murthy, D. P., Blischke, W. R..: Warranty Management and Product Manufacture. Springer, London (2006)

2. Gungor, A., Gupta, S. M.: Issues in environmentally conscious manufacturing and product recovery: a survey. Computers \& Industrial Engineering, 36(4), 811-853 (1999)

3. Ilgin, M. A., Gupta, S. M.: Environmentally Conscious Manufacturing and Product Recovery (ECMPRO): A Review of the State of the Art. Journal of Environmental Management, 91(3), 563-591 (2010)

4. Lambert, A. F., Gupta, S. M.: Disassembly Modeling for Assembly, Maintenance, Reuse and Recycling. CRC press (2004)

5. Lage Jr., M., Godinho-Filho, M.: Production Planning and Control for Remanufacturing: Literature Review and Analysis. Production Planning \& Control, 23(6), 419-435 (2012)

6. Ilgin, M. A., Gupta, S. M.: Remanufacturing Modeling and Analysis. CRC Press (2012)

7. Heal, G. (1977). Guarantees and Risk-sharing. The Review of Economic Studies, 549-560.

8. Balachander, S.: Warranty signalling and reputation. Management Science, 47(9), 12821289 (2001)

9. Gal-Or, E.: Warranties as a Signal of Quality. Canadian J. Economics, 50-61 (1989)

10. Soberman, D. A.: Simultaneous Signaling and Screening with Warranties. Journal of Marketing Research, 40(2), 176-192 (2003)

11. Spence, M: Consumer Misperceptions, Product Failure and Producer Liability. The Review of Economic Studies, 561-572 (1977)

12. Lutz, N. A., \& Padmanabhan, V. (1995). Why Do We Observe Minimal Warranties? Marketing Science, 14(4), 417-441 (1995)

13. Blischke, W. R., Murthy, C. N. P.: Warranty Cost Analysis. Marcel Dekker, New York (1994).

14. Blischke, W. R.,Murthy, C. N. P.: Product Warranty Handbook. Marcel Dekker, New York (1996)

15. Blischke, W. R., Karim, M. R., Murthy, D. P.: Warranty Data Collection and Analysis, Springer (2011)

16. Alqahtani, A. Y., Gupta, S. M.: End-of-Life Product Warranty. In Northeast Decision Sciences Institute (NEDSI) Conference, Cambridge (2015)

17. Alqahtani, A. Y., Gupta, S.M.: Warranty Policy Analysis for End-Of-Life Product in Reverse Supply Chain. In 26th Production and Operations Management Society (POMS), Washington D.C. (2015)

18. Alqahtani, A. Y., Gupta, S.M.: Extended Warranty Analysis for Remanufactured Products. In International Conference on Remanufacturing (ICoR), Amsterdam (2015)

19. Alqahtani, A. Y., Gupta, S. M. Non-Renewable Basic Two-Dimensional Warranty Policy Analysis for End-Of-Life Product in Reverse Supply Chain. In Northeast Decision Sciences Institute (NEDSI) Conference, Alexandria, VA (2016)

20. Murthy, D. P., Jack, N.: Extended Warranties, Maintenance Service and Lease Contracts Modeling and Analysis for Decision-Making. Springer (2014) 